\section{Corporate Social Responsibility and employee behavior: mediating role of organizational commitment}

\author{
Mohammad Tahlil Azim \\ King Abdulaziz University, Faculty of Economics and Administration, \\ Department of Business Administration, Jeddah, Saudi Arabia
}

\begin{abstract}
Purpose - The study investigates the relationship between employees' perception about the external CSR practices of their organizations and employees' organizational commitment (affective) and job engagement, organization engagement, organizational citizenship behavior related to the individual, and organizational citizenship behavior related to the organization in the context of the Saudi banking industry.
\end{abstract}

Design/methodology/approach - The study draws its theoretical groundwork from social identity theory (Tajfel \& Turner, 1979) and social exchange theory (Blau, 1964). Data were collected through survey questionnaire, and the Mediation regression analysis is used for exploring the relationship between independent and dependent variables based on Baron \& Kenny's (1986) method.

Findings - The study observes a positive relationship between perceived CSR and organizational commitment, employee engagement and organizational citizenship behavior related to organization. However, the organizational citizenship behavior related to the individual is not observed to have linked to perceived CSR.

Originality/value - The uniqueness of this study lies on its framework and a particular aspect of CSR measurement. It conceptualizes one integrated model to build a relationship among CSR, organizational commitment, employee engagement and OCB. As the study views CSR as a competitive tool for the organizations, here the CSR activities are measured in relative rather than absolute terms, stand-alone act of an organization.

Keywords - Corporate Social Responsibility; job engagement; organizational commitment; organizational citizenship behavior; organizational engagement.
Received on

01/14/2015

Approved on

06/02/2016

Responsible editor:

Profa. Dra ${ }^{a}$. Leire San- Jose

Evaluation process:

Double Blind Review

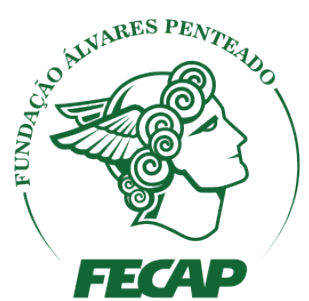

Review of Business Management 


\section{Introduction}

Corporate social responsibility (CSR) is an excellent indicator of the legitimacy of a firm. Along with western world, CSR is also gaining currency in the developing world. A recent survey regarding CSR and sustainability programs in GCC countries, including Saudi Arabia, showed that $72 \%$ and $83 \%$ of companies worldwide and in the region, respectively, indicated that CSR has become more important in the past 2 years, with $78 \%$ companies in the Middle East employing a policy for CSR/Sustainability. In the Middle East, $86 \%$ of companies rated it as a very important or important component of business strategy (Amlôt, 2013).

CSR is studied from different perspectives and dimensions. The relationship between CSR and employee attitude and behavior, perhaps, cannot be considered as an under-researched area. Most of the published studies exploring perceived CSR and attitude of employees focused either on organizational commitment (OC) (Ali, Rehman, Ali, Yousaf, \& Zia, 2010; Brammer, Millington, \& Rayton, 2007; Dhanesh, 2010; Ebeid, 2010; Maignan \& Ferrell 2001; Maignan, Ferrell, \& Hult 1999; Peterson, 2004; Turker, 2009; You et al., 2013; Zheng 2010) or job satisfaction (Riordan, Gatewood, \& Bill 1997; Tziner, Bar, Oren, \& Kadosh, 2011; Valentine \& Fleischman, 2008; You et al., 2013). However, with few exceptions (Ali et al., 2010, Zheng, 2010), most of the studies viewed them as dependent rather than mediating variables (Riordan, Gatewood, \& Bill, 1997; Valentine \& Fleischman, 2008). Moreover, all the studies involving external CSR, measured CSR in absolute terms rather than in relative terms, i.e. they take into consideration the magnitude of the philanthropic contribution of a particular organization to the community rather than its CSR contribution in comparison to others in the same industry. As far as employee behavior is concerned, most of the studies focused on organizational citizenship behavior (OCB), and on job performance (in-role behavior) (Aguilera, Rupp, Ganapathi, \& Williams, 2006; Brammer et al., 2007; Zheng, 2010) only. Very few studies considered employee engagement as an outcome of the firm's CSR performance. Albdour and Altarawneh (2012) conducted a study on internal CSR and employee engagement in the Jordanian context. Nevertheless, in recent years, there has been a great deal of attention on employee engagement. It is claimed that employee engagement is a good predictor of employee outcomes, organizational success, and financial performance (e.g. total shareholder return) (Bates, 2004; Richman, 2006). At the same time, it has been reported that employee engagement is on the decline, and there is a deepening disengagement among employees today (Bates, 2004; Richman, 2006; Saks, 2006). Evidence from surveys, management consulting, journalistic and corporate sources, show that CSR is an emerging and increasingly important driver of employee engagement (Gross \& Holland, 2010). Therefore, employee engagement as a desirable employee behavior as well as its connection to CSR deserves more investigation.

As Banks play an active role in CSR field, researchers paid particular attention to the dimensions of CSR in banks. Since many banks offer similar conditions in the same markets, competition in the banking sector is no longer just about price. Creating uniqueness in the market with the introduction of innovative products through financial engineering is constant, and competitors are very quick to replicate innovations. Therefore, creating a brand image of the bank is an important aspect of the strategic management in a high-competitive environment (Kostyuk, Mozghovyi, Riabichenko, Govorun, \& Lapina, 2012). To this end, CSR is now considered to be an appropriate tool (Brown \& Dacin, 1997; Sen \& Bhattacharya, 2001).

Even though CSR in banks has received a lot of attention from the researchers, surprisingly there has been no particular study conducted in 
the context of Saudi Arabia. However, in terms of socio-politico-economic reality, Saudi Arabia holds a prominent position in the whole Middle East and North Africa (MENA) region. In view of this dearth of research, the present study examines the impact of CSR on employee commitment and employee engagement and organizational citizenship behavior in the context of the Saudi banking industry. Based on social identity theory (Tajfel \& Turner 1979) and social exchange theory (Blau, 1964), the present paper investigates how CSR influences employee organizational commitment, job engagement, and OCB.

The uniqueness of this study lies on its framework and a particular aspect of CSR measurement. It conceptualizes one integrated model to build a relationship among CSR, organizational commitment, employee engagement and OCB. As the study views CSR as a competitive tool for the organizations, here the CSR activities are measured in relative rather than absolute terms, stand-alone act of an organization.

\section{Definition of CSR}

The present study adopts a stakeholderoriented conceptualization of CSR and depends on Barnett's (2007) definition of CSR initiatives as "a discretionary allocation of corporate resources towards improving social welfare that serves as a means of enhancing relationships with key stakeholders" (Barnett, 2007, p. 801). Stakeholders are broadly defined as any individual, group, or entity that can affect, or be affected by, an organization's activity (Freeman, 1984). According to stakeholder theory, the existence of organizations depends on their ability to integrate stakeholders' expectations into their business strategy because stakeholders provide essential resources and returns for the successful functioning and survival of organizations (Donaldson \& Preston, 1995; Roeck \& Delobbe, 2012).

\section{CSR and employee attitude and behavior: theoretical link}

Employees are one of the most important stakeholders of any organization. Since they can be affected by and also affect their organizational activities, the employees play a key role in the success or failure of their organization. This is how employees are likely to be affected by the CSR programs and react differently at work (Koh \& Boo, 2001; Peterson, 2004). Social identity theory (SIT) and social exchange theory (SET) are two widely-used theoretical frameworks that underpin the relationship between perception of CSR and employees' attitudinal and behavioral reactions (Ashforth \& Mael, 1989; Blau, 1964; Cropanzano \& Mitchell, 2005; Hogg \& Terry, 2000; Molm \& Cook, 1995; Tajfel \& Turner, 1986).

SIT was originally proposed by Tajfel and Turner (1979) as an integrative theory about the perception of psychological basis of intergroup discrimination. It is concerned with both the psychological and sociological aspects of group behavior. It studies the impact of individual perceptions, social categorization, and group distinctiveness on an individual's attitudes and behaviors (Cinnirella, 1998). According to SIT, social identification corresponds to the psychological process through which individuals classify themselves into various social groups of reference (e.g. nation, organization, political or religious affiliation, and so forth) in order to reinforce their self-esteem and overall self-concept (Hogg \& Terry, 2001; Tajfel, 1981; Tajfel \& Turner, 1986). Individuals may achieve positive self-esteem when they sense an in-group identity that differentiates them from the out-group. Thus, SIT, with its underlying self-enhancement process, is a good framework for explaining the impact of CSR on employees' attitudes (Brammer et al., 2007; Peterson, 2004; Turker, 2009). When the employees see their organization works for the well-being of the society in the form of CSR which ultimately develops a positive image in the society, they feel a sense of satisfaction and like 
to identify themselves with the organization as it enhances their self-esteem and pride (Hogg \& Terry, 2000; Tajfel, 1978).

Thus, SIT provides a rational explanation of the relationship between perceived CSR and employees' positive attitude. The relationship is likely to be stronger if the employees find that their organizations are involved in CSR activities more rigorously than their competitors are. Thus, the relative CSR is expected to be a better predictor of the CSR-attitude relationship. However, the link between CSR and positive attitude of the employees does not integrate notions of reciprocity, expectations, and mutual obligations, which are needed to understand how attitudes enhanced by identification may contribute to desirable employee behavior within the organization. It is SET that provides a better theoretical understanding of this relationship. SET highlights social behavior as the result of an exchange process (Blau, 1964). The exchange refers to a reciprocal behavior (Konovsky \& Pugh, 1994). Specifically, if employees feel happy when they are working in their organization, they are likely to support their organization as a mutual exchange. Sometimes employees may engage in voluntary behavior to reciprocate the treatment they receive from their organization (Organ, 1990). Saks (2006) argues that SET offers a stronger theoretical rationale for explaining employee engagement in the organization. Robinson, Perryman and Hayday (2004) describe engagement as a two-way relationship between the employer and employee. Individuals repay their organization through their level of engagement. That is, the amount of cognitive, emotional, and physical resources that an individual is prepared to devote in the performance of work roles is contingent upon the economic and socio-emotional resources received from the organization.
In his seminal book on social exchange, Blau (1964) argues that philanthropic donations are likely to affect the dynamics of social exchange, not only with the recipients of this action but also within the donor's own social group.

Men make charitable donations, not to earn the gratitude of the recipients, whom they never see, but to earn the approval of their peers who participate in the philanthropic campaign. Donations are exchanged for social approval, though the recipients of the donations and the suppliers of the approval are not identical, and the clarification of the connection between the two requires an analysis of the complex structures of indirect exchange (Blau, 1964, p. 92).

Based on SET, when the CSR program fulfills the expectations of the employees, they are likely to have a positive attitude, which, in turn, leads to more enthusiastic behavior from the employees in the form of OCB, employee engagement, and other desirable behaviors (Organ \& Lingl, 1995).

\section{Research framework}

In view of the research gap mentioned in the introduction, the present study has envisioned a study that offers a holistic framework, incorporating CSR, employee attitude, and employee behavior (Figure 1). The model demonstrates how employees' perception of the CSR practices of their organization affects their attitude toward organizational commitment, which ultimately affects their behavioral reaction in the form of job engagement, organizational engagement, and organizational citizenship behavior. The theoretical basis of the framework lies with SIT (Tajfel \& Turner, 1979) and SET (Blau, 1964). 


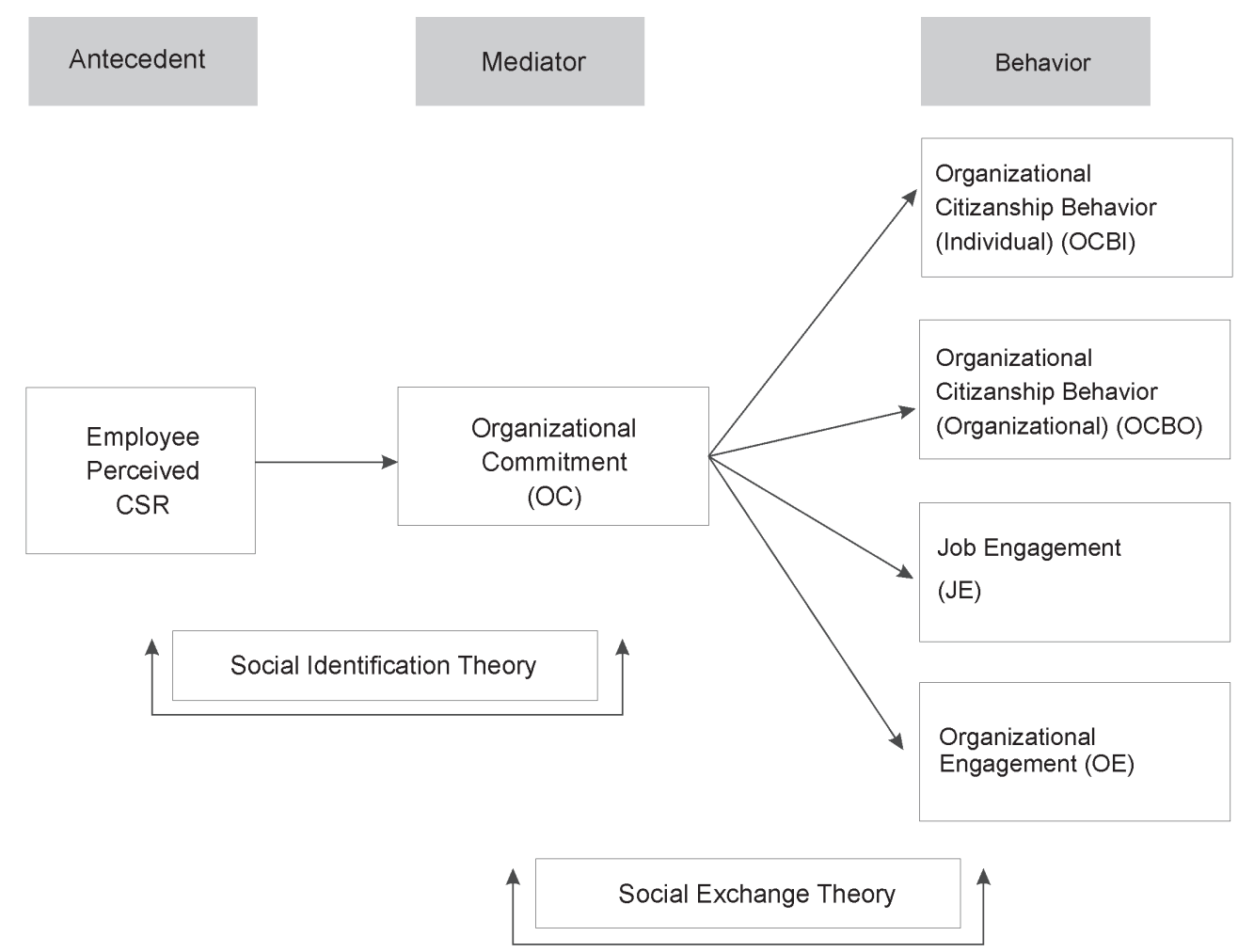

Figure 1. Research Framework

\section{Hypotheses development}

\section{I Perceived CSR and organizational commitment (OC)}

Employee perception of the work environment has drawn a lot of attention from researchers in organizational literature. It is a psychological interpretation of an organization's activities that has been seen as a predictor of individual performance, such as OCB (Moorman, 1991) and job performance (Prichard \& Karasick, 1973). Employee CSR perception refers to employees' personal evaluations and interpretations of an organization's CSR activities, which may differ from the actual CSR practices of the organization. Employee perception is subjective; it represents the employees' interpretation of an organization's activities and sense-making process (Weick, 1995). Such perception, in turn, leads to employees' attitudinal and behavioral reactions.

Organization Commitment (OC) as defined by Porter, Steers, Mowday and Boulian
(1974) is 'the relative strength of an individual's identification with and involvement in a particular organization'. They argue that an employee with this attitude believes in the goals and values of the organization, possesses willingness to exert considerable effort on behalf of the organization and holds a strong desire to retain membership in the organization. Meyer and Allen (1984) identified three types of commitment: affective, normative and continuance commitment. However, it is argued that affective commitment expresses a more holistic approach to conceptualizing about the nature of the employee relationship as it rests on the individuals' 'psychological bond' and 'loyalty to the organization' (Haque \& Azim, 2009; O’Reilly, 2008). SIT offers a plausible link between perceived CSR and organizational commitment. When the employees find that their organization is working in a socially responsible way, they feel proud of their organization and like to associate themselves with it, which, in turn, leads to a higher level of commitment to the organization. Previous research examining 
perceived CSR and organizational commitment (Ali et al., 2010; Brammer et al., 2007; Dhanesh, 2010; Ebeid, 2010; Maignan \& Ferrell, 2001; Maignan, Ferrell, \& Hult, 1999; Peterson, 2004; Turker, 2009; You et al., 2013; Zheng, 2010) found a positive relationship between the two; i.e., employee organizational commitment is found to be higher in organizations that are perceived to be socially responsible.

H1: Employees' perception of CSR activities of their organization is positively and directly related to their organizational commitment.

\subsection{Organizational commitment between perceived CSR and OCB}

Organizational Citizenship Behavior (OCB) is defined as an employee's willingness to go above and beyond the prescribed roles which he/she has been assigned (Organ, 1990). It is the willingness to give time to helping others who have work-related problems, taking steps to prevent problems with other workers, and obeying an organization's rules, regulations, and procedures, even when no one is watching. These behaviors are perceived to be derived from employees' positive work attitude, such as organizational commitment. SET provides a plausible theoretical link between organizational commitment and OCB. Previous empirical studies investigating the relationship between Organizational commitment (particularly affective commitment) and OCB observed a significant correlation between the two (Fu, 2013; O’Reilly \& Chatman, 1986; Shore \& Wayne, 1993).

$\mathrm{OB}$ literature suggests a distinction between two dimensions of OCB: OCB directed to individuals (hereafter referred to as OCBI) and $\mathrm{OCB}$ directed to the organization (hereafter referred to as OCBO) (McNeely \& Meglino, 1994). This distinction has implications for the present research, particularly in that the relative importance of affect and cognition might depend on whether OCBI or OCBO is more relevant. If we assume that OCB is a deliberate attempt to maintain the balance in a social exchange between employees and the organization (i.e., a cognitionoriented explanation), it is sensible to suggest that this behavior is more directly intended to benefit the organization. Hence, OCBO is more likely to be a direct function of what employees perceive about the CSR activities of their organization. In contrast, OCBI, primarily involving helping individuals at work, seems to have only indirect implications, at best, for maintaining balance in the organization - employee transaction. Such behaviors might indeed reflect a natural expression of employees' affect at work, as many social psychological studies have suggested (e.g., Isen \& Levin, 1972), rather than reflecting employees' deliberate attempt to restore the balance with the organization (Lee \& Allen, 2002).

As mentioned earlier, employees' organizational commitment has a positive relationship with their perception of CSR activities of their organization. Again, organizational commitment has a positive influence on OCB. An emotionally attached employee is logically perceived to devote his/her abilities and power to perform activities that go beyond his/her formal job description. Consequently, when the organization performs CSR, the employees become committed because of enhanced selfimage or greater sense of fairness, and they, in return, perform voluntary behavior within the workplace. Thus the study hypothesizes the mediating relationship of organizational commitment in between perceived CSR and both OCBI and OCBO.

H2: The relationship between employee perception of CSR and OCBI is mediated by organizational commitment.

H3: The relationship between employee perception of CSR and OCBO is mediated by organizational commitment 


\subsection{Organizational commitment between perceived CSR and employee engagement}

Schaufeli, Salanova, Gonzalez-Rom and Bakker (2002, p. 74) define employee engagement "as a positive, fulfilling, work-related state of mind that is characterized by vigor, dedication, and absorption." They also maintain that it is not a momentary and specific state but, rather, "a more persistent and pervasive affective-cognitive state that is not focused on any particular object, event, individual, or behavior" (p. 74). According to Saks (2006, p. 602), "engagement is not an attitude; it is the degree to which an individual is attentive and absorbed in the performance of their roles." The focus of engagement is one's formal role performance rather than extra-role and voluntary behaviors (Saks, 2006). In line with roles employees perform in an organization, two types of engagements are identified: job engagement (JE) and organization engagement (OE). Job engagement refers to the psychological presence of an individual in his/her job related role and organization engagement represents the engagement of an employee in performing his/ her role as a member of the organization (Kahn, 1990).

According to the tenet of the SET, one can argue that when an employee develops psychological bondage with the organization, he/she will engage him/herself more passionately in his/her job role and organizational role. Saks (2006) observes a significant positive relationship between employee (both job and organizational) engagement and job satisfaction, organizational commitment, and organizational citizenship behavior as well as a significant negative relationship to intention to quit. The empirical study of May, Gilson and Harter (2004) found that meaningfulness along with safety and availability was significant antecedents of employee engagement. Performance of CSR by the organization may provide a higher sense of meaningfulness in the job in the sense that the employees may feel they are not working for the organization simply for their bread and butter; rather, they are part of an institution that serves the community to make the world a better place to live in. Albdour and Altarawneh (2012) observed a significant positive relationship between perceived internal CSR of the employees and their job and organization engagement but their study did not consider any mediating factors. However, in consonance with the mediating role of organizational commitment in between perceived CSR activities and OCB, the present study envisions a similar role of organizational commitment between perceived CSR and both types of employee engagement.

H4: The relationship between employee perception of CSR and job engagement is mediated by organizational commitment.

H5: The relationship between employee perception of CSR and organization engagement is mediated by organizational commitment.

\section{Overview of Saudi banking industry and CSR}

Saudi Arabia is the largest economy of the MENA region, with 2798.43 billion Riyal (equivalent to around $\$ 745$ billion) GDP (at 2014 prices). There are 23 commercial banks operating in Saudi Arabia, including 12 domestic and 11 foreign banks. According to the Saudi Arabia Monetary Agency (SAMA), there were 1,912 branches by the end of 2014. Commercial banks' net profits stood at 40.2 billion Riyal (equivalent to around $\$ 10.7$ billion) in 2014 , denoting a rise of $6.5 \%$ over the preceding year. (Saudi Arabia Monetary Agency [SAMA], 2015)

As Saudi Arabia is predominately a Muslim country governed under the principles of Quranic law, a reflection of Islamic beliefs and views is observed in the life of its citizens. According to Shari'a (the Islamic code of law), charging and collecting interest is strictly prohibited. However, the conventional banking system is essentially 
based on interest. Consequently, there is a natural tendency among the Saudis to bank with Shari'a compliant banks. Therefore, all the banks operating in Saudi Arabia consider the issue and act accordingly. Amongst the domestic banks, five are completely Shari'a compliant banks and the rest maintain a Shari'a - banking window along with their conventional banking practices. The avoidance of interest by the clients, even in Shari'a compliant banks, is reflected in the bank's deposit structure. A review of bank deposits in 2014 shows that demand deposits, which are no interest-bearing, comprise $57.2 \%$ of the total deposits, followed by time and saving deposits $(23.1 \%)$ and other quasi-monetary deposits (10.9\%). It simply implies that the cost of capital in Saudi banks is relatively cheaper than that of their counterparts in many other countries. Therefore, it is expected that the Saudi banks can afford a greater involvement in discretionary CSR activities. A review of the annual reports of the Saudi domestic banks indicates that all the banks maintain external CSR programs in one way or the other. The most common CSR initiatives include investment in education, training, and health care, addressing the problems of the underprivileged segment of the society, and creating job opportunities for the unemployed (SAMA, 2015).

\section{Methodology}

\section{I Participants}

Participants included 266 employees working in different branches of the 12 domestic banks of Saudi Arabia, of which $73.7 \%$ are male and $26.3 \%$ are female. The lower level of female participants corresponds to the lower level of female participation in the workforce. In Saudi banks, female employees work in branches dedicated to serving female clients only. The average age group of the participants is 30-40 years and the average work experience with the existing bank is $5-10$ years.

\subsection{Procedures}

The data for this study was collected by graduate and undergraduate students of a large public university in Saudi Arabia. A total of 500 questionnaires were distributed to the employees of different banks located in Jeddah, Ryiad, Hail, and Makka. The survey included a cover letter that informed participants about the purpose of the study. Participation was voluntary and participants were informed that their responses would remain anonymous and confidential. The questionnaire was originally prepared in English; however, to make it comprehensible to the respondents, each question was translated into Arabic and both the English and Arabic version of the questions were included in the questionnaire. A total of 266 usable questionnaires were returned, representing a response rate of 53.2 percent. The data were then analyzed using SPSS version 16.0.

\section{$7 \cdot 3$ Scales}

All the scales used for the study were adopted from previous studies. Participants indicated their response on a five-point Likerttype scale with anchors (1) strongly disagree to (5) strongly agree. The reliability of the scale was measured with the estimate of Cornbach's Alpha $(\alpha)$. Factor loading was calculated to see whether all questions used for predicting the relevant variables contributed adequately.

Perceived CSR: As the study measures relative rather than absolute CSR of the banks involved in the study, we employed the two-item scale used by Valentine and Fleishman (2008) with slight modification. In fact, the focus was to measure the relative external CSR of the banks. The item includes, 'In comparison to other banks in Saudi Arabia, my bank is more socially responsible organization that serves the greater community ' (factor loading .832), and 'In comparison to other banks in Saudi Arabia, my bank gives more time, money and other resources to socially responsible causes ' (factor loading .832). The composite reliability coefficient, 
Cornbach's Alpha $(\alpha)$, is calculated and found to be 0.83 , which is satisfactory according to Nunnally’s (1978) guidelines.

Organizational Commitment: The sixitem scale used by Saks (2006) was employed to measure Affective commitment. A sample item for commitment includes, 'I feel a strong sense of belongingness to my organization' or 'I would be happy to work at my organization until I retire'. Here all the items except one, receive factor loading above .724. The item, 'Working at my organization has a great deal of personal meaning to me' receives factor loading of .198 only. Therefore, we excluded the item from the scale and found the overall factor loading .844 .

Job and organization engagement: A five-item scale for job engagement and a sixitem scale for organizational engagement used by Saks (2006) were used for this study. The items assess the participant's psychological presence in their job and organization. A sample item for job engagement is, 'Sometimes I am so into my job that I lose track of time' and for organization engagement, 'One of the most exciting things for me is getting involved with things happening in this organization.' All of the job engagement items loaded 0.70 or higher $(\alpha=.747)$. All six of the organization engagement items loaded 0.70 or higher $(\alpha=.892)$.

OCBI and OCBO: Two four-item scales adopted by Saks (2006) were used for OCBI and OCBO. A sample item for OCBI is, 'I willingly give my time to help others who have work-related problems'; and for OCBO, 'I take action to protect the organization from potential problems.' All of the OCBI items loaded 0.70 or higher $(\alpha=.859)$. However, for OCBO, two items loaded above 0.80 and two items loaded below 0.3. The two items with poor factor loading were, 'I attend functions that are not required but that help the organizational image' and 'I offer ideas to improve the functioning of the organization.' Initially including all four items, $\alpha$ came out to be .187; this was unacceptable so we dropped the above-mentioned two items with poor factor loading and observed a momentous increase in $\bigotimes$ value that turned out to be .761 .

\subsection{Mediation regression analysis}

Mediation regression analysis is used for exploring the relationship between independent and dependent variables (Baron \& Kenny, 1986). To test mediation, this study estimated three regression equations:

a) Regression of mediator on independent variable; i.e., organizational commitment on perceived RCSR (Relative Corporate Social Responsibility);

b) Regression of dependent variable on independent variable; i.e., JE, OE, OCBI and OCBO on perceived RCSR;

c) Regression of dependent variable on both independent variable and on the mediator; i.e., JE, OE, OCBI and OCBO on both perceived RCSR and organizational commitment.

In order to establish the mediating effect, the results of the three steps must fulfill the following criteria:

a) The independent variable must have a significant effect on the mediator in the first step;

b) The independent variable must have a significant effect on the dependent variable in the second step, and;

c) Mediator must have a significant effect on the dependent variable in the third step.

When all three criteria are achieved, the effect of the independent variable on the dependent variable must be less in step (3) than in step (2). In addition, after controlling for the mediator, the full mediating effect is achieved if the independent variable has no effect on the dependent variable, while partial mediation is achieved if the independent variable has a significant effect on the dependent variable (Zheng, 2010). 


\section{Result}

Table 1 represents the mean and standard deviations of different variables used in the study. The scores of means for all the variables are above 3, which indicates that the respondents demonstrate above-average feeling for different variables included in the study, as 3 is the midpoint.

Table 2 shows whether independent variable 'perceived RCSR' is capable of influencing organizational commitment. The computed value of $F[F=85.53 ., \mathrm{df}=(1,266)]$ shows that the model is statistically significant. The influence of perceived RCSR is found to be statistically significant $(\mathrm{t}=7.187, \mathrm{p}=0.000)$ and positive $(\beta=0.411)$. Thereby it supports H1. It is also visible that 'perceived Relative CSR' explains as much as $54.3 \%$ of the variation of 'organizational commitment.'

Table 1

Variables with mean and standard deviation

\begin{tabular}{ccc}
\hline Variables & Mean & Standard Deviation \\
\hline RCSR & 3.88 & .88 \\
OC & 3.68 & .75 \\
JE & 3.89 & .55 \\
OE & 3.90 & .73 \\
OCBI & 3.77 & .78 \\
OCBO & 3.34 & .75 \\
\hline
\end{tabular}

Note. RCSR = Relative Corporate Social Responsibility; $\mathrm{OC}=$ Organizational Commitment; JE = Job Engagement; $\mathrm{OE}=$ Organizational Engagement; $\mathrm{OCBI}$ = Organizational Citizenship Behavior Related to Individual; OCBO = Organizational Citizenship Behavior Related to Organization.

Table 2

\section{Regression of perceived CSR over organizational commitment}

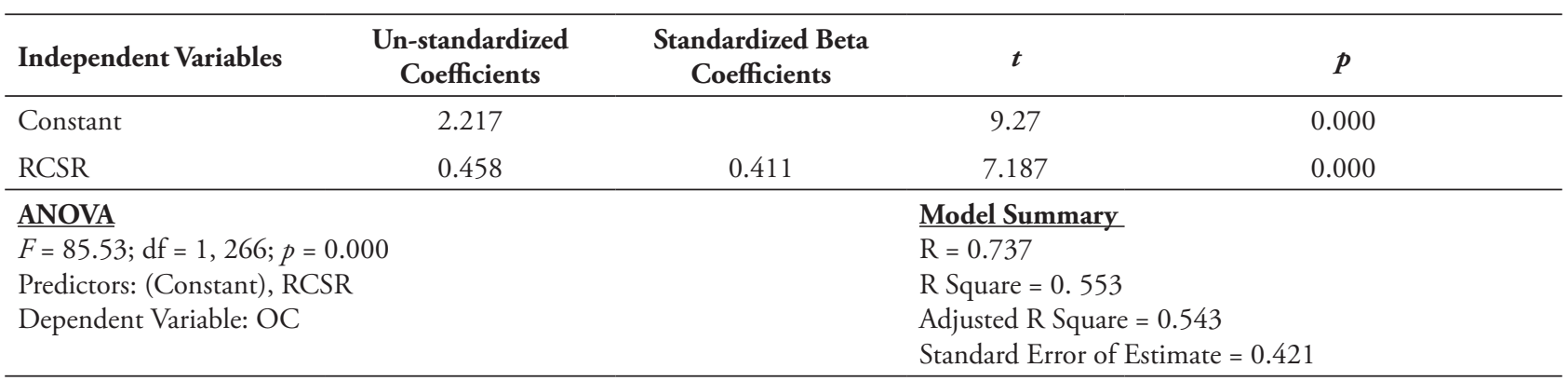

In order to check the common method biases resulting from raters, item characteristics and context, Harman's single factor test was conducted. The result of the test is presented in table 3 . The $33 \%$ variance explained by a single factor shows that the common method bias is not a major concern in this study (less than 50\% cut-off point). (Podasakoff, MacKenzie, Lee, \& Podsakoff, 2003).

Table 3

\section{Total variance explained}

\begin{tabular}{|c|c|c|c|c|c|c|}
\hline \multirow{2}{*}{ Component } & \multicolumn{3}{|c|}{ Initial Eigenvalues } & \multicolumn{3}{|c|}{ Extraction Sums of Squared Loadings } \\
\hline & Total & $\%$ of Variance & Cumulative \% & Total & $\%$ of Variance & Cumulative \% \\
\hline OCBI & 1.177 & 33.249 & 33.249 & 1.177 & 33.249 & 33.249 \\
\hline OCBO & .999 & 27.309 & 60.558 & & & \\
\hline JE & .823 & 21.443 & 82.001 & & & \\
\hline $\mathrm{OE}$ & .741 & 17.999 & 100.000 & & & \\
\hline
\end{tabular}

Note. Extraction Method: Principal Component Analysis.

OCBI = Organizational Citizenship Behavior Related to Individual; OCBO = Organizational Citizenship Behavior Related to

Organization; JE = Job Engagement; $\mathrm{OE}=$ Organizational Engagement 
Table 4 shows the mediation regression analysis based on Baron and Kenny's (1986) recommendation. Here we run three regressions for each dependent variable. In the case of OCBI, we observe in steps 2 and 3 that the $\beta$ coefficient turns out to be insignificant and thus we can conclude that there is no significant relationship between perceived RCSR and OCBI; hence, the mediating role of organizational commitment is beyond question. Therefore, we reject $\mathrm{H} 2$. As regards OCBO, it is observed that in step 2 , perceived RCSR has a significant influence on OCBO, but in step 3, the relationship turns out to be insignificant whereas the relationship between $\mathrm{OCBO}$ and $\mathrm{OC}$ remains significant. This means the influence of RCSR on OCBO is fully mediated by OC. Thus, it supports our H3.
Concerning JE, a significant positive relationship between JE and RCSR is observed in step 2. In step 3, the relationship between RCSR and JE becomes weaker and significant at the 5\% level, while it remains significant at a $1 \%$ level for the relationship between JE and OC. This also indicates the influence of RCSR on JE is fully mediated by $\mathrm{OC}$ and, consequently, supports $\mathrm{H} 4$. As for OE, it is found that $\mathrm{OE}$ is significantly influenced by employee RCSR perception in step 2. Step 3 also indicates a significant influence of RCSR and OC on OE. However, the effect of RCSR on OE is less in step 3 (.152) than in step 2 (.418). Thus, we observe that OC has a partial mediating role in relationship between perceived RCSR and OE. Therefore, the study partially supports $\mathrm{H} 5$.

Table 4

Regression of Dependent Variables (DV) on Independent Variable (IV) and Mediator (OC)

\begin{tabular}{|c|c|c|c|}
\hline DV & Regression Model & $\begin{array}{c}\text { IV (CSR) } \\
\beta \text { coefficient }\end{array}$ & Mediating Effect \\
\hline OCBI & $\begin{array}{c}\text { OC (MV) on CSR (IV) } \\
\text { OCBI (DV) on CSR (IV) } \\
\text { OCBI (DV) on CSR (IV) and OC (MV) }\end{array}$ & $\begin{array}{l}.411^{*} \\
.169 \\
.040 \\
.508 \\
\end{array}$ & No \\
\hline ОСВО & $\begin{array}{c}\text { OC (MV) on CSR (IV) } \\
\text { OCBO (DV) on CSR (IV) } \\
\text { OCBO (DV) on CSR (IV) and OC (MV) }\end{array}$ & $\begin{array}{l}.411^{*} \\
.237^{*} \\
.012 \\
.605^{*} \\
\end{array}$ & Full \\
\hline $\mathrm{JE}$ & $\begin{array}{c}\text { OC (MV) on CSR (IV) } \\
\text { JE (DV) on CSR (IV) } \\
\text { JE (DV) on CSR (IV) and OC (MV) }\end{array}$ & $\begin{array}{l}.411^{*} \\
.326^{*} \\
.109^{* *} \\
.527^{*}\end{array}$ & Full \\
\hline $\mathrm{OE}$ & $\begin{array}{c}\text { OC(MV) on CSR (IV) } \\
\text { OE (DV) on CSR (IV) } \\
\text { OE (DV) on CSR (IV) and OC (MV) }\end{array}$ & $\begin{array}{l}.411^{*} \\
.418^{*} \\
.152^{*} \\
.647^{*}\end{array}$ & Partial \\
\hline
\end{tabular}

Note. ${ }^{*}$ significant at $1 \%$ level, ${ }^{* *}$ significant at $5 \%$ level

$\mathrm{OCBI}=$ Organizational Citizenship Behavior Related to Individual; $\mathrm{OC}=$ Organizational Commitment; $\mathrm{MV}=$ Moderating Variable; CSR = Corporate Social Responsibility; OCBO = Organizational Citizenship Behavior Related to Organization; JE = Job Engagement; $\mathrm{OE}=$ Organizational Engagement.

\section{Discussion}

The study envisions a model incorporating employees' perceived CSR to the larger community as the independent variable, organizational commitment as the mediating variable, and employee job engagement, employee organizational engagement, organizational citizenship behavior related to the individual and organizational citizenship behavior related to the organization as the dependent variable. It finds a significant positive correlation between 
employees' perceived CSR and organizational commitment. A similar result was also found in the studies of Maignan, Ferrell and Hult (1999), Maignan and Ferrell (2001), Peterson (2004), Brammer et al. (2007), Turker (2009), Ebeid (2010), Ali et al. (2010), Dhanesh (2010), Zheng (2010), You et al. (2013).

Such a relationship is grounded on the basic tenet of the Social Identity Theory that explains an individual's attachment and attraction to a group. Valentine and Fleischman (2008) suggest that individuals prefer organizations that promote business ethics (Jose \& Thibodeaux, 1999; Trevino, Butterfield, \& McCabe 1998; Trevino \& Nelson, 2004) and CSR is a natural extension of organizational ethics, which involves answering the requirements of stakeholders, with particular focus on societal issues and challenges. Thus, when an individual finds his/ her organization is involved in CSR, he/she feels good about his/her organization because of an enhanced self-image and delight, which ultimately leads to a higher sense of emotional attachment to the organization.

The study does not find any significant relationship between OCBI and perceived CSR or OCBI and organizational commitment. This finding is contrary to the findings of most of the studies seeking a relationship between organizational commitment and OCB (Fu, 2013; O'Reilly \& Chatman 1986; Shore \& Wayne 1993) or CSR and OCB (Bozkurta \& Balb, 2012; Zheng, 2010). There may be several explanations for the result. First, most of the previous studies consider OCB as an integrated concept and did not bifurcate it into OCBI and OCBO. Therefore, their findings did not reflect the exact relationship between OCBI and organizational commitment. Second, the employees may perform OCBI out of their own sense of responsibility or interpersonal relationship that has nothing to do with the commitment to the organization. Third, the study is based on external CSR only, not based on internal CSR, such as organizational justice, training etc. Internal CSR is considered to be more comprehensible predictor of relationship between commitment and OCBI. This study finds a significant relationship between $\mathrm{OCBO}$ and perceived CSR fully mediated by Organizational commitment. A similar result was found by Zheng (2010) in the Chinese context. This relationship makes sense. It validates the argument of Lee and Allen (2002, p. 135) as they suggest, "If we assume that OCB is a deliberate attempt to maintain the balance in a social exchange between employees and the organization, it is sensible to suggest that this behavior is more directly intended to benefit the organization. Hence, OCBO is more likely to be a direct function of what employees perceive about the CSR activities of their organization."

The study observes a significant positive relationship between employee perception of CSR and employee job engagement and organizational engagement. The relationship between CSR perception and job engagement is fully mediated by organizational commitment while it is partially mediated in the case of organizational engagement. This is in line with the proposed hypothesis of Rupp, Ganapathi, Aguilera and Williams (2006). Similar results were also found by Zheng (2010) and Albdour and Altarawneh (2012). Corresponding to the Social Exchange Theory, an employee having strong psychological bondage with the organization is more likely to reciprocate by performing his required duties more seriously in the workplace. Moreover, meaningfulness of the job, which is an antecedent of employee engagement, is inserted in the organization's external CSR (May et al., 2004). It gives a sense of benevolence pertaining to their job. They feel they are working for the betterment of humankind, not just for narrow economic gain. Consequently, it boosts their engagement towards their job as well as organization.

\section{ro Conclusion}

Being responsible for the needs of the society and conducting ethical business practices are now the standard expectation of the 
employees. Employees are not only concerned about the paycheck, they also look for meaning in their job. Involvement in CSR activities by the organization offers such a link for the employees. They like to identify themselves with a sociallyresponsible organization since it heightens their self-image and, in turn, they reciprocate through positive attitudes and behaviors such as greater job satisfaction, a higher sense of organizational commitment, intense engagement within the job and organization, a greater level of organizational citizenship behavior, and so on. The present study explores the relationship between perception of employees about the external CSR practices of their organizations in relative terms and employees' organizational commitment and job engagement, organization engagement, organizational citizenship behavior related to the individual and organizational citizenship behavior related to organization in the context of the Saudi banking industry. It is observed that, like most of the previous studies, there is a positive relationship between perceived relative CSR and employee organizational commitment, employee engagement, and organizational citizenship behavior related to the organization. It implies that the management of the banks in Saudi Arabia should consider the involvement in external CSR as one of the key determinants of maintaining a motivated and enthusiastic workforce. Contributing money to philanthropy is not a one-way approach; it also pays off in terms of more dedicated employees.

\section{Limitations and direction for further studies}

The study is based on external CSR that focuses on corporate philanthropy or discretionary behavior only. However, CSR encompasses a wider range of issues. Carroll (1979, 1991) identified four types of CSR activities: economic, legal, ethical and philanthropic. Schwartz and Carroll (2003) discard philanthropy as a separate CSR activity and consider it to be a part of either economic or ethical activities. Because of this, the results of the study may lack comparability to the studies that cover all aspects of CSR. The study combines different variables in a new framework and only the theoretical explanations were used to validate the Model. However, it would have been better if further validation has been sought by the experts in the field. Further studies may focus on wider ranges of CSR, cover more industries rather than just one single industry like banks only. To have greater insight about the view of Saudi organizations regarding CSR, in-depth qualitative studies are also worth exploring.

\section{References}

Aguilera, R., Rupp, D. E., Ganapathi, J., \& Williams, C. A. (2006). Justice and social responsibility: A social exchange model. Paper presented at the Society for Industrial/Organizational Psychology Annual Meeting, Berlin.

Albdour, A. A., \& Altarawneh I. I. (2012). Corporate social responsibility and employee engagement in Jordan. International Journal of Business and Management, 7(16), 89-105.

Ali, I., Rehman, K. U., Ali, S. I., Yousaf, J., \& Zia, M. (2010). Corporate social responsibility influences, employee commitment and organizational performance. African Journal of Business Management, 4(12), 2796-2801. Retrieved from http://www.academicjournals.org/ AJBM/abstracts/abstracts/abstracts2010/4Oct/ Ali\%20et\%20al.htm

Amlôt, R. (2013). Corporate social responsibility: A viable tool for sustainable development in the MENA Region. Retrieved from http://www. cpifinancial.net/features/post/19491/corporatesocial-responsibility-a-viable-tool-for-sustainabledevelopment-in-the-mena-region

Ashforth, B. E., \& Mael, F. (1989). Social identity theory and the organization. Academy of Management Review, 14(1), 20-39. 
Barnett, M. L. (2007). Stakeholder influence capacity and the variability of financial returns to corporate social responsibility'. Academy of Management Review, 32(3), 794-816.

Baron, R. M., \& Kenny, D. A. (1986). The moderator-mediator variable distinction in social psychological research: Conceptual, strategic, and statistical consideration. Journal of Personality and Social Psychology, 51(6), 1173-1182.

Bates, S. (2004). Getting engaged. HR Magazine, 49(2), 44-51.

Blau, P. (1964). Exchange and power in social life. New York: Wiley.

Bozkurta, S., \& Balb, Y. (2012). Investigation of the relationship between corporate social responsibility and organizational citizenship behavior: A research. International Journal of Innovations in Business, 1(1), 40-59

Brammer, S., Millington, A., \& Rayton, B. (2007). The contribution of corporate social responsibility to organizational commitment. International Journal of Human Resource Management, 18(10), 1701-1719.

Brown, T. J., \& Dacin, P. A. (1997). The company and the product: Corporate associations and consumer product responses. Journal of Marketing, 61(1), 68-84.

Carroll, A. B. (1979). A three dimensional model of corporate performance. Academy of Management Review, 4, 497-505.

Carroll, A. B. (1991). The pyramid of corporate social responsibility: Toward the moral management of organizational stakeholders. Business Horizons, 34(4), 39-48. doi:10.1016/0007-6813(91)90005-G

Cinnirella, M. (1998). Exploring the temporal dimension of social identity: The concept of possible social identities European. Journal of Social Psychology, 28(2), 227-248.
Cropanzano, R., \& Mitchell, M. S. (2005). Social exchange theory: An interdisciplinary review. Journal of Management, 31(6), 874-900.

Dhanesh, G. S. (2010). The view from within: Internal publics and CSR. Journal of Communication Management, 16(1), 39-58.

Donaldson, T., \& Preston, L. E. (1995). The stakeholder theory of the corporation: Concepts, evidence, and implications. Academy of Management Review, 20(1), 65-91.

Ebeid, A. Y. H. (2010). Corporate social responsibility and its relation to organizational commitment. Problems and Perspectives in Management, 8(2), 76-93.

Freeman, R. E. (1984). Strategic management: $A$ stakeholder approach. Boston: Pitman.

Fu, Y.-K. (2013). High-performance human resource practices moderate flight attendants organizational commitment and organizational citizenship behavior. Social Behavior and Personality: An International Journal, 41(7), 1195-1208.

Gross, R., \& Holland, B. (2010). Corporate social responsibility and employee engagement: Making the connection [Whitepaper]. Retrieved from http://www.mandrake.ca/bill/images/ corporate_responsibility_white_paper.pdf

Haque, M. M., \& Azim, M. T. (2009). The effect of recognition practice over affective commitment and OCB: An empirical study in Bangladesh. Independent Business Review, 2(2), 65-81.

Hogg, M. A., \& Terry, D. J. (2000). Social identity and self categorization processes in organizational contexts. Academy of Management Review, 25(1), 121-140.

Isen, A. M., \& Levin, H. (1972). Effect of feeling good on helping: Cookies and kindness. Journal of Personality and Social Psychology, 21(3), 384-388.

Jose, A., \& Thibodeaux, M. S. (1999). Institutionalization of ethics: The perspective 
of managers. Journal of Business Ethics, 22(2), 133-143.

Kahn, W. A. (1990). Psychological conditions of personal engagement and disengagement at work. Academy of Management Journal, 33(4), 692-724. Retrieved from http://www.jstor.org/ stable/256287

Koh, H. C., \& Boo, E. H. Y. (2001). The link between organizational ethics and job satisfaction: A study of managers in Singapore. Journal of Business Ethics, 29(4), 309-324.

Konovsky, M., \& Pugh, D. S. (1994). Citizenship behavior and social exchange. Academy of Management Journal, 37(3), 656-669.

Kostyuk. A. N., Mozghovyi, Y. I., Riabichenko, D. A., Govorun, D. A., \& Lapina, Y. H. (2012). Corporate social responsibility in banks: An international overview [Working Paper]. Ukrainian Academy of Banking of the National Bank of Ukraine, Ukraine.

Lee, K., \& Allen, N. J. (2002). Organizational citizenship behaviour and workplace deviance: The role of affect and cognitions. Journal of Applied Psychology, 87(1), 131-142.

Maignan, I., \& Ferrell, O. C. (2001). Antecedents and benefits of corporate citizenship: An investigation of French businesses. Journal of Business Research, 51(1), 37-51.

Maignan, I., Ferrell, O. C., \& Hult, G. T. M. (1999). Corporate citizenship: Cultural antecedents and business benefits. Journal of the Academy of Marketing Science, 27(4), 455-469.

May, D. R., Gilson, R. L., \& Harter, L. M. (2004). The psychological conditions of meaningfulness, safety and availability and the engagement of the human spirit at work. Journal of Occupational and Organizational Psychology, 77(1), 11-37.

McNeely, B. L., \& Meglino, B. M. (1994). The role of dispositional and situational antecedents in prosocial organizational behavior: An examination of the intended beneficiaries of prosocial behavior. Journal of Applied Psychology, 79(6), 836-844.

Meyer, J. P., \& Allen, N. J. (1984). Testing the 'side bet theory' of organizational commitment: Some methodological considerations. Journal of Applied Psychology, 69(3), 372-378.

Molm, L. D., \& Cook, K. S. (1995). Social exchange and social networks. In K. S. Cook, G. A. Fine, \& J. S. House (Eds.), Sociological perspectives on social psychology (pp. 209-235). Boston, MA: Allyn \& Bacon.

Moorman, R. H. (1991). Relationship between organizational justice and organizational citizenship behaviors: Do fairness perceptions influence employee citizenship. Journal of Applied Psychology, 76(6), 845-855.

Nunnally, J. (1978). Psychometric Theory (2nd ed.). New York: McGraw Hill.

O'Reilly, C. (2008). Corporations, culture and commitment: Motivation and social control in organization. California Management Review, 50(2), 85-101.

O'Reilly, C., \& Chatman, J. (1986). Organizational commitment and psychological attachment: The effects of compliance, identification, and internalization on prosocial behavior. Journal of Applied Psychology, 71(3), 492-499.

Organ, D. W. (1990). The motivational basis of organizational citizenship behavior. In B. M. Staw, \& L. L. Cummings (Eds.), Research in organizational behavior (pp. 43-72). Greenwich, CT: JAI Press.

Organ, D. W., \& Lingl, A. (1995). Personality, satisfaction, and organizational citizenship behavior. Journal of Social Psychology, 135(3), 339-350.

Peterson, D. K. (2004). The relationship between perceptions of corporate citizenship and 
organizational commitment. Business and Society, 43(3), 269-319.

Podsakoff, P. M., MacKenzie, S. B., Lee, J.-Y., \& Podsakoff, N. P. (2003). Common method biases in behavioral research: A critical review of the literature and recommended remedies. Journal of Applied Psychology, 88(5), 879-903. doi:10.1037/0021-9010.88.5.879

Porter, L. W., Steers, R. M., Mowday, R. T., \& Boulian, P. V. (1974). Organisational commitment, job satisfaction and turnover among psychiatric technicians. Journal of Applied Psychology, 59(5), 603-609.

Pritchard, R. D., \& Karasick, B. W. (1973). The effects of organizational climate on managerial job performance and job satisfaction. Organizational Behavior and Human Decision Processe, 9(1), 126-146.

Richman, A. (2006). Everyone wants an engaged workforce: How can you create it? Workspan, 49, 36-39.

Riordan, C. M., Gatewood, R. D., \& Bill, J. B. (1997). Corporate image: Employee reactions and implications for managing corporate social performance. Journal of Business Ethics, 16(4), 401-412.

Robinson, D., Perryman, S., \& Hayday, S. (2004). The drivers of employee engagement [IES Report n. 408]. Institute for Employment Studies, Brighton.

Roeck, R. D. \& Delobbe, N. (2012). Do environmental CSR initiatives serve organizations' legitimacy in the oil industry? Exploring employees' reactions through organizational identification theory. Journal of Business Ethics, 110(4), 397-412.

Rupp, D., Ganapathi, J., Aguilera, R. V., \& Williams, C. A. (2006). Employee reactions to corporate social responsibility: An organizational justice framework. Journal of Organizational Behaviour, 27(4), 537-543.

Saks, A. M. (2006). Antecedents and consequences of employee engagement. Journal of Managerial Psychology, 21(7), 600-619. doi: http://dx.doi. org/10.1108/02683940610690169

Saudi Arabian Monetary Agency. Fifty First Annual Report. Government of Saudi Arabia', 2015. Retrieved from http://www.sama.gov.sa/enUS/EconomicReports/AnnualReport/5600_R_ Annual_En_51_Apx.pdf

Schaufeli, W. B., Salanova, M., Gonzalez-Rom, V., \& Bakker, A. B. (2002). The measurement of burnout and engagement: A confirmatory factor analytic approach. Journal of Happiness Studies, 3(1), 71-92.

Schwartz, M. S., \& Carroll, A. B. (2003) Corporate social responsibility: A three-domain approach. Business Ethics Quarterly, 13(4), 503-530.

Sen, S., \& Bhattacharya, C. B. (2001). Does doing good always lead to doing better? Consumer's reactions to corporate social responsibility. Journal of Marketing Research, 38(2), 225-243.

Shore, L. M., \& Wayne, S. J. (1993). Commitment and employee behavior: Comparison ofaffective commitment and continuance commitment with perceived organizational support. Journal of Applied Psychology, 78(5), 774-780.

Tajfel, H. (1978). Social categorization, social identity, and social comparison. In H. Tajfel (Ed.), Differentiation between social groups: Studies in the social psychology of intergroup relations (pp. 61-76). London: Academic Press.

Tajfel, H. (1981). Human groups and social categories. Cambridge: Cambridge University Press.

Tajfel, H., \& Turner, J. C. (1979). An integrative theory of intergroup conflict. In W. G. Austin 
\& S. Worchel (Eds.), The social psychology of intergroup relations (pp. 33-47). Monterey, CA: Brooks/Cole.

Tajfel, H., \& Turner, J. C. (1986). The social identity theory of intergroup behavior. In $S$. Worchel, \& W. G. Austin (Eds.), Psychology of intergroup relations (pp. 7-24). Chicago: Nelson.

Trevino, L. K., Butterfield, K. B., \& McCabe, D. L. (1998). The ethical context in organizations: Influences on employee attitudes and behaviors. Business Ethics Quarterly, 8(3), 447-476.

Trevino, L. K., \& Nelson, K. A. (2004), Managing business ethics: Straight talk about how to do it right (3rd ed.). New York: John Wiley \& Sons.

Turker, D. (2009). How corporate social responsibility influences organizational commitment. Journal of Business Ethics, 89(2), 189-204.

Tziner, A., Bar, Y., Oren, L., \& Kadosh, G. (2011). Corporate social responsibility, organizational justice and job satisfaction: How do they interrelate, if at all? Revista de Psicología del Trabajoy de las Organizaciones, 27(1), 67-72.

Valentine, S., \& Fleischman, G. (2008). Ethics programs, perceived corporate social responsibility and job satisfaction. Journal of Business Ethics, 77(2), 159-172.

Weick, K. E. (1995). Sense making in organizations. Thousand Oaks, CA: Sage.

You, C.-S., Huang, C.-C., Wang, H.-B., Liu, K.-N., Lin, C.-H., \& Tseng, J.-S. (2013). The relationship between corporate social responsibility, job satisfaction and organizational commitment. International Journal of Organizational Innovation, 5(4), 65-77.

Zheng, D. (2010). The Impact of employees' perception of corporate social responsibility on job attitudes and behaviors: A study in China (Master thesis). Singapore Management University, Victoria St, Cingapura. Retrieved from http://ink.library.smu.edu. sg/etd_coll/72 


\section{Appendix - Questionnaire}

Relative Corporate Social Responsibility (RCSR) developed by S. Valentine \& G. Fleishman (2008) (Used with slight modification to fit for Comparative measure)

1. In comparison to other banks, my bank is a more socially responsible organization that serves the greater community

2. In comparison to other banks, my bank gives more time, money and other resources to socially responsible causes.

Job Engagement (JE) developed by Alan M. Saks (2006)

1. I really "throw" myself into my job.

2. Sometimes I am so into my job that I lose track of time.

3. This job is all consuming; I am totally into it.

4. My mind often wanders and I think of other things when doing my job (R).

5. I am highly engaged in this job.

Organizational Engagement (OE) developed by Alan M. Saks (2006)

1. Being a member of this organization is very attractive.

2. One of the most exciting things for me is to getting involved with things happening in this organization.

3. I am really not into the "goings-on" in this organization (R).

4. Being a member of this organization make me come "alive."

5. Being a member of this organization is exciting for me.

6. I am highly engaged in this organization.

Organizational Citizenship Behavior related to individual (OCBI) developed by Alan M. Saks (2006)

1. I willingly give my time to help others who have work-related problems.

2. I adjust my work schedule to accommodate other employees' requests for time off.

3. I give up time to help others who have work or non-work problems.

4. I assist others with their duties.

Organizational Citizenship Behavior related to Organization (OCBO) developed by Alan M. Saks (2006)

1. I attend functions that are not required but that help the organizational image.

2. I offer ideas to improve the functioning of the organization.

3. I take action to protect the organization from potential problems.

4. I defend the organization when other employees criticize it.

Organizational Commitment (OC) by Alan M. Saks (2006)

1. I would be happy to work at my organization until I retire

2. Working at my organization has a great deal of personal meaning to me.

3. I really feel that problems faced by my organization are also my problems.

4. I feel personally attached to my work organization.

5. I am proud to tell others I work at my organization.

6. I feel a strong sense of belongingness to my organization. 
About the authors:

1. Mohammad Tahlil Azim, PhD in Entrepreneurship, King Abdulaziz University, Saudi Arabia.

Email: tahlilazim@yahoo.com.

\section{Contribution of each author:}

Contribution

Mohammad Tahlil Azim

Definition of research problem

Development of hypotheses or research questions ( empirical studies )

3. Development of theoretical propositions ( theoretical Work )

4. Theoretical foundation/ Literature review

5. Definition of methodological procedures

6. Data collection

7. Statistical analysis

8. Analysis and interpretation of data

9. Critical revision of the manuscript

10. Manuscript Writing

11. Other (please specify which) 